\title{
Between Empires and PeERs: Hasmonean Foreign Policy under Alexander Jannaeus
}

\author{
Julia Wilker \\ University of Pennsylvania
}

\begin{abstract}
During the reign of Alexander Jannaeus (103-76 BCE), Judea underwent a number of significant changes. This article explores one of them: the fundamental shift in foreign policy strategy. This shift becomes most apparent in the king's decision to not renew the alliance with Rome, which had been a hallmark of Hasmonean foreign policy since the days of Judas Maccabaeus. However, a close analysis of Alexander Jannaeus' policy regarding other foreign powers demonstrates that the end of the Judean-Roman alliance did not happen in a vacuum. It is shown that under Alexander Jannaeus, the Hasmonean state adopted a different strategy towards imperial powers by focusing on deescalation and ignorance rather than alliances. In contrast, interactions with other rising states in the vicinity, such as the Nabateans and Itureans, increased. This new orientation in foreign policy reflected changes in Hasmonean identity and self-definition; Judea did not need imperial support to maintain its independence anymore but strived to increase its status as a regional power.
\end{abstract}

Key words: Hasmoneans, Alexander Jannaeus, Jewish-Roman relations, foreign relations.

The reign of Alexander Jannaeus (103-76 BCE) constituted a seminal period in the history of Hellenistic Judea; his rule signifies both the acme and a turning point of the Hasmonean state. The length of his tenure as king - second only to that of his father, John Hyrcanus (135-105/104 BCE) - stands in significant contrast to that of his predecessor, Aristobulus I, who died after having ruled for less than a year. Yet Alexander Jannaeus had a remarkable reign not only for its long duration; it was also under his command that the boundaries of Hasmonean Judea were extended beyond ever before. These successes stand out even more considering that Alexander Jannaeus acceded to the throne during a time of crisis. Aristobulus I had continued the process of expansion begun by John Hyrcanus, and during his short reign, large parts of Galilee were added to Judea; however, he also left the country, the dynasty, and the court in turmoil. After his father's death in 105/4 BCE, Aristobulus seized the throne violently and against John Hyrcanus' will, imprisoning his own mother and all of his brothers, except Antigonus. ${ }^{1}$ The murder

\footnotetext{
${ }^{1}$ Josephus, $B J 1.70-71 ; A J 13.301-302$.
} 
of the latter was eventually ordered in what Flavius Josephus describes as an elaborate court intrigue. ${ }^{2}$ When Aristobulus died after a long sickness, his widow, Salina Alexandra, freed the imprisoned relatives and established Alexander Jannaeus as king. ${ }^{3}$ The new ruler secured his power by killing one of his brothers, whom he considered a potential rival, but afterwards, he seems to have gained general acceptance rather swiftly. ${ }^{4}$

The following 27 years of Alexander Jannaeus' reign were shaped by two dynamics that would redefine the character of Hasmonean Judea: first, the growth of an internal opposition against the king, which he oppressed violently and without mercy. Second, an almost uninterrupted series of military campaigns that were driven both by Alexander Jannaeus' insatiable hunger for expansion and the need to defend Judea against equally expansionist neighbors and imperial powers. The reign of Alexander Jannaeus has thus rightly been presented as a period of ambiguity, shaped by internal conflict and external victories. ${ }^{5}$ However, a third aspect that sets the reign of Alexander Jannaeus' apart from those of his predecessors has received less attention: the fundamental reorientation of Hasmonean foreign policy.

This strategic shift in foreign policy becomes most apparent in the fact that Alexander Jannaeus decided not to renew the friendship with Rome. Given that the Roman Republic had been one of the oldest political allies of the emerging independent Judea and beyond doubt the most significant one, this decision at first appears surprising. The numerous treaties that Rome and the Hasmoneans concluded between the time of Judas Maccabaeus and the reign of John Hyrcanus have been long discussed in modern scholarship. ${ }^{6}$ In contrast, the question of why these relationships ceased to exist for several decades before Judea was finally conquered by Pompey the Great in 63 BCE has received less attention. ${ }^{7}$ In the following analysis, this decision by Alexander Jannaeus will be reassessed in the context of his foreign policy in general, including his relations with imperial powers other than Rome and regional political players, such as the Nabateans. This contextualization demonstrates that the non-renewal of the Roman alliance was neither the result of sudden disagreements nor a hostile act. Instead, it was part of a new strategy that reflected Judea's new status as a regional power.

2 Josephus, $B J$ 1.72-77; AJ 13.303-309.

3 Josephus, $B J 1.85 ; A J 13.320-321$.

${ }^{4}$ Josephus, $B J 1.86 ; A J 13.323$.

${ }_{5}^{5}$ Among the more recent works, cf. Dąbrowa 2010a, 86-93; Rappaport 2013, 306-342; Atkinson 2016a, $100-133$.

${ }^{6}$ Among the vast amount of scholarship see, for instance, Giovannini-Müller 1971; Fischer 1974; Timpe 1974; Fischer 1981; Rajak 1981; Gruen 1984, 731-751; Baltrusch 2002, esp. 85-113; Eilers 2008; Wilker 2008; Shatzman 2012; Eilers 2013; Seeman 2013; Rocca 2014a; Zollschan 2017; Dąbrowa, forthcoming.

${ }^{7}$ See esp. Rappaport 1968 and Stern 1981; more recently Dąbrowa 2010a, 92; Rocca 2014a; Rocca 2014b. These studies take a chronological approach that helps to understand not only the complicated sequence of events but also the dynamics among the various players and conflicts. In contrast, this article offers a structural analysis and is organized according to the main foreign parties that Alexander interacted with in order to understand his broader strategy. 


\section{Rome and Judea}

The first alliance between the Maccabees under Judas' leadership and Rome dates back to $161 \mathrm{BCE}$, when Judea was still far from achieving independence. ${ }^{8}$ Nonetheless, the treaty stipulated that the two parties would offer each other military help if needed and if possible. ${ }^{9}$ No such help was sent by the Roman Republic, although the Maccabean movement soon came under severe duress when Seleucid re-enforcements invaded Judea again and Judas fell on the battlefield in $160 \mathrm{BCE} .{ }^{10}$ Nonetheless, his successor, Jonathan, renewed the treaty in $144 \mathrm{BCE},{ }^{11}$ as did Simon, who succeeded his brother Jonathan in 142 BCE and under whose leadership Judea achieved independence from the Seleucid Empire. ${ }^{12}$ Simon's son, John Hyrcanus, followed his predecessors' example after he had re-enforced Judean independence after the death of Antiochus VII in 129 BCE. ${ }^{13} \mathrm{He}$ also renewed the treaty once again, presumably around $112 \mathrm{BCE}$, after two decades of a reign during which he had significantly expanded the borders of Judea. ${ }^{14}$ Until the end of Hyrcanus' rule, the alliance with Rome was thus a hallmark of Hasmonean practice and reflects a longstanding tradition of friendly relations.

The importance of this formalized friendship is demonstrated not only by the multiple treaties themselves but also by their presentation in the First Book of Maccabees. Its account of the first agreement between Rome and Judas Maccabaeus is preluded by a praise, the famous laus Romanorum. ${ }^{15}$ The Jews were striving for this friendship because the Romans, so the text stipulates, possessed unsurpassed military power, were loyal to their friends, and were keen on forming new alliances. The historicity of the passage has been widely discussed in modern scholarship; ${ }^{16}$ however, regardless of when the passage was composed, the admiration toward the Roman Republic - particularly its foreign policy - still resonated with the author of 1 Maccabees, who also expected his

81 Macc 8.17-32; Josephus, AJ 12.415-419, cf. 2 Macc 4.11.

91 Macc 8.28; cf. Josephus, $A J$ 12.418. For a discussion of this point see esp. Baltrusch 2002, 92-98; Wilker 2008, 197; Seeman 2013, 113-118.

${ }^{10}$ Giovannini - Müller (1971, 166-167) and Dąbrowa (2010a, 34) rightly point out that the chronology suggests that the envoys sent to Rome did not made it back to Judea before Judas' death. However, this does not impact the general analysis presented here as Rome did not intervene militarily in any of the following crises, either.

111 Macc 12.1-4; Josephus, AJ 13.163-165; Goldstein 1976, 445-446; Baltrusch 2002, 98-102; Seeman 2013, 143-146 (each with references to previous scholarship).

121 Macc 14.16-18, 24, 40, 15.15-23; Josephus, $A J$ 13.227, 14.145-148. Josephus erroneously puts the decree in the last passage into the time of Julius Caesar: Giovannini - Müller 1971, 160-165; Timpe 1974, 146-149; Goldstein 1976, 492-500; Gruen 1984, 748-751; Schwartz 1993; Baltrusch 2002, 103-105; Dąbrowa 2010a, 58; Seeman 2013, 162-171.

13 Josephus, AJ 13.259-266; Dąbrowa 2010a, 70; Baltrusch 2002, 106-108; Shatzman 2012, 56-65; Seeman 2013, 184-194 (each with references to previous scholarship).

${ }^{14} \mathrm{Cf}$. the decree from Pergamum, quoting a decree originally from Athens, dating to 106/105 BCE: Josephus, AJ 14.247-255. Josephus erroneously puts this decree in the time of Julius Caesar: Giovannini Müller 1971, 156-160; Timpe 1974, 148; Baltrusch 2002, 106, 108-110; Eilers 2008; Shatzman 2012, 65-68; Eilers 2013, 156-162; Seeman 2013, 194-200.

151 Macc 8.1-16.

${ }^{16}$ Cf., for instance, Stemberger 1983, 6-12; Goldstein 1976, 346-357; Hadas-Lebel 1987, 736-745; Baltrusch 2002, 88 and 180; Seeman 2013, 209-218. 
audience to embrace this positive image. Accepting the common dating of 1 Maccabees to the reign of John Hyrcanus, the passage can thus also illuminate the Hasmonean perspective on Rome prior to the rule of Alexander Jannaeus. ${ }^{17}$

Against this background, it is even more surprising that no further diplomatic contacts between Judea and Rome are recorded until 64/63 BCE. ${ }^{18}$ Aristobulus I - who acceded to the throne in 105/4 BCE - was the first Hasmonean ruler who apparently failed to renew the existing treaty with Rome. Whether this break was intentional is impossible to discern, considering that Aristobulus only ruled for a year. ${ }^{19}$ Yet, it was under Alexander Jannaeus that a new direction and strategy in Hasmonean foreign relations was firmly implemented. Modern scholars have explained this surprising shift in foreign policy in different ways, ranging from a deliberate act by either the Judeans or Rome ${ }^{20}$ to negating such a break of tradition and maintaining that former relations remained in place. ${ }^{21}$ These approaches offer important insights into the evolution of Hasmonean policy and/ or Rome's imperial strategy; however, the temporary end of Judean-Roman relations must be interpreted in its general context. In fact, it will be shown that Alexander Jannaeus diverted from the path laid out by his predecessors in other foreign relations, and the end of the formal friendship with Rome was part of a larger reconfiguration.

17 The last historical event mentioned in the laus Romanorum is the Achaean War of 146 BCE: 1 Macc 8.9-10. The anti-monarchical tone of 1 Macc 8.4, 12-14 suggests that the work was finalized before Aristobulus I formally assumed kingship in $105 \mathrm{BCE}$, the only cursory reference to the deeds of John Hyrcanus in 1 Macc 16.23-24 indicates that the work was written before the end of his reign. For the relevance of Rome in 1 Maccabees' narrative and its implications see Seeman 2013, esp. 204-218.

18 Josephus, $A J 14.36$ quotes Strabo that Aristobulus II sent a golden vine to Rome as a gift that was

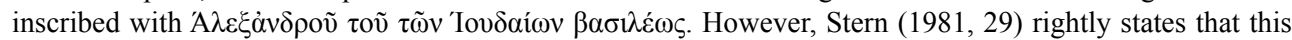
should not be read as hinting at any formal relations between Alexander Jannaeus and Rome; rather, Strabo misread the inscription or Josephus quoted him incorrectly.

${ }^{19}$ Cf. Rappaport 1968, 329. However, it appears that Aristobulus did not send an embassy to Rome immediately after his accession to the throne and thus diverted from the example set by his predecessors, cf. Seeman 2013, 220 (with a summary of previous scholarship).

${ }^{20}$ See esp. Rappaport (1968), who reconstructs diplomatic ties of Judea with Parthia and Mithridates of Pontus that were considered being against Roman interests. He also argues that Rome perceived Alexander Jannaeus as an opponent to its anti-piracy policy in the Eastern Mediterranean. Zollschan (2017, 258-268) also argues that Rome did not renew the alliance because of Hasmonean ties with the Parthian Empire and the charge of not taking action against piracy. For a critical discussion of these points, see Rocca 2014a, 270-274, 278-283 (the same arguments are put forward in Rocca 2014b). Seeman (2013, 227-230 and 241-243) maintains that the Hasmonean kings avoided sending aristocratic ambassadors to Rome because they feared that the Senate might side with the internal, anti-monarchical opposition. Dąbrowa (2010a, 93) argues that Alexander Jannaeus focus on expansion prevented a renewed engagement in foreign alliances. A similar argument is put forward by Shatzman (2012), who argues that whereas John Hyrcanus largely followed his predecessors' example in the relations with Rome, his expansionist policy would have led sooner or later to a break with the powerful ally in the West.

${ }^{21}$ See Rocca 2014a, 274-276. The same conclusion is implied in arguments that explain the imperial restraint of Cleopatra III, who refrained from annexing Judea after the "War of the Scepters," with a supposedly still existing alliance between Rome and Judea under Alexander Jannaeus (see below, no. 45). 


\section{A well-known threat: Alexander Jannaeus and the Seleucids}

The Hasmonean state grew out of the Maccabean revolt against the Seleucid Empire, and the former imperial overlords continued to pose a severe threat to its independence. Like most of his predecessors, Alexander Jannaeus had to fight off Seleucid attempts to bring the country back under imperial control or at least force the local ruler into vassalage. The most serious of these attempts occurred around $90 \mathrm{BCE}$, when Demetrius III invaded Judea. Josephus records this invasion in the context of the growing troubles within Jewish society and describes Demetrius entering the country on invitation and with the strong military support of the Jewish opposition against Alexander Jannaeus. ${ }^{22}$ The re-enforced Seleucid troops inflicted a devastating defeat on the king's forces near Shechem. However, Demetrius was deprived of his victory when many of the Jews who had previously supported him subsequently switched sides, prompting the Seleucid king to leave Judea. Josephus does not give any more details that would permit reconstruction of the actual events or the motivation for this surprising decision, yet it saved Judea's independence and Alexander Jannaeus' throne. ${ }^{23}$

The coalition between the anti-Hasmonean opposition and a Seleucid invader made for a unique situation, yet it still allows some insights into Alexander Jannaeus' political strategy. Given Demetrius' advances, the king had no choice but to fend off these attacks, just as every other Hasmonean before him had done. However, he did not follow another precedent. Judea had gained and secured its independence through the internal weakness of the Seleucid power structure. Jonathan, Simon, and John Hyrcanus not only took advantage of the empire's disintegration but actively capitalized on internal dynastic rivalries. To relieve military pressure, they sided with the enemy of whoever posed the greatest threat to Judea in the present situation. If that was impossible, they agreed to enter temporary alliances with Seleucid rulers to divert their attention from Judea. ${ }^{24}$ Alexander Jannnaeus must have been aware of this well-tried political strategy, but despite Demetrius' initial successes, he did not reach out to the king's brother and rival,

22 Josephus, $B J$ 1.92-94; $A J$ 13.376-377; cf. Ehling 2008, 244. The invasion of Demetrius III is also referenced in several of the Dead Sea Scrolls; cf., with summaries of earlier scholarship, Eshel 2008, 117131; Dąbrowa 2010a, 87-90; Dąbrowa 2010b; Atkinson 2016b (with responses by Albert I. Baumgarten and Sandra Gambetti in the same volume, 58-65 and 66-67).

23 Josephus, BJ 1.93-95; AJ 13.377-379.

${ }^{24}$ Cf. Josephus, $A J$ 13.273. For individual cases, see, for instance, 1 Macc 9.69-72; Josephus, $A J$ 13.32-33 (Jonathan and Bacchides); 1 Macc 10.3-6; Josephus, $A J$ 13.37-38 (Jonathan and Demetrius I); 1 Macc 10.17-20, 47, 59-65, 88-89; Josephus, AJ 13.43-45, 83-85 (Jonathan and Alexander Balas); 1 Macc 11.23-37, 44, 47-51; Josephus, AJ 13.124-129, 133-134, 136-142 (Jonathan and Demetrius II); 1 Macc 11.57-59; Josephus, AJ 13.145-153 (Jonathan and Antiochus VI); 1 Macc 11.43-45; Josephus, AJ 13.188-190 (Jonathan and Tryphon); 1 Macc 13.36-40, 14.38-39; Josephus, BJ 1.53 (Simon and Demetrius II); 1 Macc 15.26; Josephus, $A J$ 13.223-224 (Simon and Antiochus VII); Josephus, $A J$ 13.247-248, 250-251; Diod. 34.1.5; Plut. Mor. 184F; Porphyry, BNJ 260 F 32.18 (John Hyrcanus and Antiochus VII); Josephus, AJ 13.269 (John Hyrcanus and Alexander Zabinas). For a discussion of these individual agreements cf. Dąbrowa 2010a, 44-45 (for the agreement between Jonathan and Bacchylides); 46-54 (for Jonathan and Demetrius II and Alexander Balas, respectively); 54-55 (Jonathan and Antiochus VI); 55 (Jonathan and Tryphon); 59 (Simon and Demetrius II); 68 (John Hyrcanus and Antiochus VII); Shatzman 2012, 50-51 for the Seleucid changing alliances of John Hyrcanus. 
Philip I, let alone forge an agreement with him. ${ }^{25}$ He proceeded in a similar way in 88/87 BCE, when Antiochus XII Dionysus invaded Judea. The Seleucid king crushed through the defense works along the Chabarsaba-Joppa-line, but Alexander Jannaeus made no attempt to join forces with Philip I against the common enemy. ${ }^{26}$

This strategical shift indicates that Alexander Jannaeus interpreted the internal state of the Seleucid Empire, its impact on Judea, and the worth of alliances with inner-Seleucid rivals differently than his predecessors. He may have regarded the empire as weaker than in previous decades and thus as a lesser threat. At first glance, Demetrius' invasion proved him wrong. However, Josephus suggests that Alexander was not alone in his assessment. According to his account, Demetrius owed his initial successes to the Jewish opposition that had invited the Seleucid king to Judea and fought on his side. This surprising move supports the view that Demetrius was largely perceived as weak. Only a rather weak Seleucid king would have been regarded by oppositional religious groups as a feasible ally who, even in the event of a military victory, would not pose a severe threat to the Temple. ${ }^{27}$ For the Jewish opposition, it was thus Demetrius' weakness that made him an acceptable partner; for Alexander Jannaeus, he was an enemy he could face on his own.

Yet this weakness - a reflection of the altered geopolitical situation - was presumably not the only reason for Alexander to refrain from forging an agreement with either Demetrius or Philip I, at this point the Seleucid rival for the throne. ${ }^{28}$ Previous Hasmoneans had played their cards well and derived benefits from their alliances with changing Seleucid partners. The nature of these coalitions was never in question; they were purely pragmatic and never conceived as more than temporary by either side. ${ }^{29}$ However, recent history also offered enough examples of Seleucid partners who soon betrayed the agreements and turned against their former Hasmonean partners. ${ }^{30}$ None of these shifts in allegiance had been surprising, yet Alexander Jannaeus apparently concluded that no Seleucid was worth trusting. Instead of playing diplomatic games and risking betrayal, he avoided alliances with any Seleucid competitor for the throne. ${ }^{31}$ Instead, he did not provoke any conflict with whoever was in charge of Seleucid troops near Judea's borders and tried his best to evade military conflict. When conflict was inevitable, he preferred to fight the battles himself than call other imperial troops for support.

${ }^{25}$ Cf. Josephus, $A J$ 13.384-386; Dąbrowa 2010b, 178.

26 Josephus, BJ 1.99-100; AJ 13.389-390; Dąbrowa 2010a, 89-90. Alexander Jannaeus' defense works did not succeed in putting the Seleucid troops to a halt, yet Antiochus did not stop to punish Judea for its resistance but proceeded toward the East. It has to be noted that Syncellus, p. 426 records victories of Alexander Jannaeus' troops against the Seleucid forces that are not mentioned by Josephus, cf. Dąbrowa 2010a, 89-91. Shortly afterwards, his forces were beaten by the Nabateans under Obodas II in the Hauran, and Antiochus died in battle. Obodas also died shortly after the battle and was succeeded by Aretas III: Bowersock 1996, 24-25. For dating the episode to 84 BCE instead, see Wenning 1994, 4.

27 Dąbrowa (2010b, 177) rightly points out that the opposition apparently did not call upon the Nabatean king Obodas for help.

${ }^{28}$ Cf. Ehling 2008, esp. 245.

${ }^{29}$ Cf. above, no. 24.

${ }^{30}$ Cf., for instance, 1 Macc 11.53; Josephus, AJ 13.147 (Demetrius II); 1 Macc 12.46-48; Josephus, $B J 1.49 ; A J 13.192$ (Tryphon); 1 Macc 15.26-36 (Antiochus VII).

31 Cf. Stern 1981, 30. 


\section{Ptolemaic infighting in Judea}

Some of the considerations that informed Alexander Jannaeus' approach toward the Seleucids also become evident in his interaction with the second imperial power in Judea's vicinity: Ptolemaic Egypt. The Ptolemies generally posed a much lesser threat to Judea than the Seleucids. However, it was Ptolemy IX Lathyrus who brought Alexander Jannaeus close to the brink of destruction. This conflict arose when in $103 \mathrm{BCE}$, the Hasmonean king turned his expansionist ambitions toward the Mediterranean coast and besieged Ptolemais-Acco, a long-standing ally of the dynasty in Alexandria. ${ }^{32}$ Under duress, the city appealed to Ptolemy IX Lathyrus for help..$^{33}$ It is unclear why the city council did not address the court in Alexandria under Cleopatra III and Ptolemy X but the latter's expelled brother on Cyprus; perhaps they (correctly) assumed that he would react more swiftly and decisively. Yet, when Ptolemy IX landed with an army, a certain Demaenetus had convinced the citizens of Ptolemais that the ruler did not help their interests, and they closed the city gates to him as well. ${ }^{34}$ Despite this surprising new situation, Alexander Jannaeus immediately signaled that he had no intention to fight against Lathyrus and withdrew his forces from Ptolemais. ${ }^{35}$ Just as in his general approach toward the Seleucids, the Hasmonean king had not provoked the confrontation; in fact, he tried to avoid any conflict with a Ptolemaic army, even if the potential opponent did currently not rule over Egypt. However, in contrast to the deliberate ignorance he showed toward Seleucid dynastic struggles, Alexander Jannaeus turned those among the Ptolemies to his own advantage.

Faced with Ptolemy IX Lathyrus' presence on the Mediterranean shore, Alexander tried to turn the threat into an advantage and sought the king's help against other coastal communities. He offered Lathyrus 4,000 talents if he got rid of Zoelus, the tyrant of Stratonos Pyrgos and Dor. The details of this arrangement are unknown, but Ptolemy acted and removed Zoelus. ${ }^{36}$ The initiative thus shows that Alexander Jannaeus was shrewd enough to turn an imperial threat into a potentially advantageous alliance. This shrewdness became even more evident when it turned out that the Judean king had, at the same time, secretly communicated with Lathryus' rivaling relatives, Cleopatra III and Ptolemy X. ${ }^{37}$ In Josephus' account, the coalition against Zoelus is presented as a mere cover to disguise the backchannel diplomacy with Alexandria; however, it may well have been a parallel attempt to divert Lathyrus' ambitions. In the end, the threat posed by Lathyrus proved to be more concerning for Judea, and Alexander Jannaeus was thus glad to accept the help of Cleopatra III.

32 Josephus, $A J$ 13.324. For the strategic importance of Acco-Ptolemais, see Cohen - Van't Dack 1989, 124-127; Dąbrowa 2010a, 86; Seeman 2013, 220.

33 Josephus, $A J 13.328$.

34 Josephus, $A J 13.330-331$.

35 Josephus, $A J 13.334$.

36 Josephus, $A J$ 13.334-335; Ziegler 1972, 714; Dąbrowa 2010a, 86.

37 Josephus, $A J$ 13.334. For the long conflict between Cleopatra III, Ptolemy X, and Ptolemy IX Lathyrus, see Whitehorne 1994, 132-148; 1995, 197-205; Hölbl 1994, 183-189; Huß 2001, 646-651. For the war in Judea, see in particular Van't Dack 1981; 1989; Atkinson 2010a, 108-117. 
Enraged by Alexander Jannaeus' breach of trust, Ptolemy turned his troops toward Judea and inflicted a devastating defeat on the Hasmonean forces in the battle of Asophon. ${ }^{38}$ The atrocities, including acts of cannibalism, that Josephus describes based on various sources give testimony to how fiercely this war was fought. ${ }^{39}$ Although most of the civilian victims were Judeans, the conflict soon became mainly a war between competing Ptolemaic factions. Cleopatra III, in concord with Ptolemy X, was alarmed by Lathyrus' landing at the Levantine coast, and even more so by his successes in Judea. With the campaign, Ptolemy IX took revenge against Alexander Jannaeus, but it was far more important to bring Judea and the coastline under his control and use them as a bridgehead against Egypt. ${ }^{40}$ It was this threat that caused Cleopatra III to answer Alexander Jannaeus' call for help. At the head of her army, the queen conquered Ptolemais but did not stop there. Ptolemy IX led a branch of the troops toward Damascus, although he had to return soon to protect Pelusium against his brother's advancing army. ${ }^{41}$ Cleopatra herself also turned inland, where she concluded a treaty with Alexander Jannaeus at Scythopolis. ${ }^{42}$ The details of Cleopatra's route, the objectives of her expedition, and the terms of the alliance with the Judean king are unknown. However, despite the gaps in the evidence and the rather unique situation, the conflict offers insights into Alexander Jannaeus' overall strategy toward imperial powers.

As seen in his conduct toward the Seleucids, Alexander Jannaeus was highly cautious and conflict avoidant in his interactions with any imperial powers. This also applies to Ptolemy IX, whose arrival near the scene at Ptolemais prompted the Hasmonean to lift the siege and even attempt to reach an agreement. However, he must have known that Ptolemy IX would not pass over the opportunity to establish himself on the shore. Against this background, Alexander Jannaeus' outreach to Cleopatra III appears as a smart diplomatic move that helped to push Ptolemy IX out of the country and safeguard Judea's integrity. This cooperation thus demonstrates that Alexander Jannaeus knew how to read the international political situation - including the internal Ptolemaic conflicts - well enough to use existing tensions to his advantage..$^{43}$ It also demonstrates that in times of urgency and crisis, he was willing to form alliances even with imperial powers, something that he avoided at all costs in regard to the Seleucids. Alexander Jannaeus apparently did not judge the Alexandrian branch of the dynasty as an immediate threat, an assessment that soon proved to be correct. According to Josephus, high-ranking Jewish officials in Cleopatra's administration and army - namely Ananias and Chelkias - convinced the queen that annexing Judea would estrange and enrage the Jews in Egypt and elsewhere. Because of this advice, Cleopatra abstained from restoring the former Ptole-

38 Josephus, $B J$ 1.86; $A J$ 13.335-347; cf. also Bagnall 1976, 52.

39 Josephus ( $A J 13.344,347$ ) cites Timagenes (BNJ 88 F 6), Nicolaus of Damascus (BNJ $90 \mathrm{~F} 93$ ), and Strabo (BNJ $91 \mathrm{~F} \mathrm{12)}$ as his sources. For references to this conflict in the Dead Sea Scrolls, see esp. Amusin 1977, esp. 123-146; Cohen 1989, 33-35; Eshel 2008, 91-100 and 101-115.

40 Cf. Josephus, $A J 13.329$.

41 Josephus, AJ 13.352; cf. Van’t Dack 1981; Whitehorne 1994, 140-141; 1995, 202-203; Huß 2001, 651.

42 Josephus, $A J$ 13.353-355; Huß 2001, 650.

43 The fact that Ptolemy IX in 109/108 BCE, then still in power in Alexandria, had sent 6000 men to support Antiochus IX Cyzicenus against John Hyrcanus in Samaria may have fueled this conflict even further (Josephus, AJ 13.278-279); cf. Huß 2001, 637. 
maic province of Koile Syria. ${ }^{44}$ This account might bear a kernel of truth, and Alexander Jannaeus may have even employed existing contacts with Jews in the higher ranks of the Ptolemaic administration to forge the alliance. However, there were likely additional reasons for Cleopatra to accept and recognize Hasmonean rule over Judea.

Rome did not intervene in the armed conflict between Cleopatra III and Ptolemy X fought on Judean soil, nor did the Republic take a direct stance in the inner-dynastic quarrel. Yet it was widely known that a balance of power in the Eastern Mediterranean was at the core of Roman strategic interests in the region. Cleopatra III must have been aware that a Ptolemaic expansion toward Judea and the Levantine coast would have prompted a Roman diplomatic intervention, and so did Alexander Jannaeus. Forming an alliance with the Ptolemaic queen was thus a safe and smart decision; it removed the imminent threat posed by Lathyrus without the broader danger of being swallowed by the dynamics of imperial expansion. ${ }^{45}$

During his reign, Alexander Jannaeus faced three invasions by imperial armies: two by the Seleucids under Demetrius III and Antiochus XII Dionysus and one by Ptolemy IX Lathyrus, which was fended off with the help of Cleopatra III. Although spread over 25 years, Alexander Jannaeus' policy toward the imperial powers in his vicinity remained fairly consistent. First and foremost, he tried to avoid conflict with the superior Seleucid or Ptolemaic forces and, if possible, evaded direct confrontation. This evasive strategy is best demonstrated in his immediate withdrawal from Acco-Ptolemais once Ptolemy IX Lathyrus appeared on the shore, although the previous support of the city by Zoelus had not affected his plans. ${ }^{46}$ In the case of Antiochus XIII, Alexander Jannaeus attempted to stop the invasion through defensive means, but once these had fallen, he did not interfere with the Seleucid march against the Nabateans. All of this indicates that Alexander Jannaeus was set on keeping interactions - friendly or hostile - with imperial powers at a minimum. Yet, this restraint in the approach toward major powers was not based on lack of knowledge; in fact, the alliance with Cleopatra III shows that Alexander Jannaeus was well aware of the internal tensions and rivalries among the imperial dynasties. However, even Jannaeus' pact with Cleopatra was only born out of necessity in the dangerous situation of Lathyrus' invasion and, as seen above, under the correct assumption that a Ptolemaic annexation of Judea was not a realistic possibility. In his approach toward the main Hellenistic Empires, Alexander Jannaeus thus chose deliberate ignorance and defensive passivity whenever possible. However, his foreign relations strategy was also shaped by other dynamics, interests, and contestants.

44 Josephus, $A J$ 13.354-355, cf. $A J$ 13.287; Stern 1981, 30, 37-38; Hölbl 1994, 167; Whitehorne 1995, 197-199; Van’t Dack 1989, 130-131.

${ }^{45}$ Stern 1981, 38; cf. also Whitehorne 1995, 198; Hölbl 1994, 188-189; Atkinson 2016a, 116. However, the aforementioned erroneously consider the Judean alliance with Rome to be still in existence at this time. Huß $(2001,645)$ also stresses that already the decree from Pergamum (Josephus, $A J$ 14.247-255) labels Ptolemy X, the "King of Alexandria," as a Roman friend and ally. Alexander Jannaeus may therefore have expected that his later alliance with Ptolemy X and his mother Cleopatra III would be met with favor in Rome. However, since there are no interactions between Alexander Jannaeus and Rome recorded, it appears doubtful that such considerations played a major part in the decision-making process of the Hasmonean king.

${ }^{46}$ Cf. Josephus, $A J$ 13.326-327. 


\section{A regional power and its peers}

In his report of Alexander Jannaeus' reign and the king's foreign policy, Flavius Josephus focuses on the main imperial powers: the Seleucids and the Ptolemies. This focus is no surprise, given the historian's overall agenda and the sources he had at his disposal. However, this emphasis gives the wrong impression of Alexander Jannaeus' political strategies. Demetrius III and Ptolemy IX Lathyrus posed an immediate threat to the Hasmonean state, yet the main contacts of the Judean king, militarily and diplomatically, were with his immediate neighbors, emerging regional powers with whom Judea now interacted - and quarreled - as equals.

The main counterparts of the Hasmonean state were the Nabateans, whose early political history is still difficult to reconstruct. ${ }^{47}$ The first relations between the two parties are recorded during the time of the Maccabean revolt, yet the details and the respective interests of both parties remain unclear. ${ }^{48}$ However, by the end of the second century BCE, the Nabateans had begun to follow their expansionist ambitions, just like their Hasmonean neighbors. ${ }^{49}$ Both the Nabatean kingdom and Judea benefitted from the structural weakness of the Seleucid Empire and, having established themselves on the political map of the Near East, sought to become more than petty kingdoms. Both slowly carved out their roles as regional powers, and although Alexander Jannaeus managed to expand the borders of Judea further than any of his predecessors, the Nabatean kings Aretas II, Obodas I, and Aretas III were even more successful. ${ }^{50}$ For instance, shortly before $84 \mathrm{BCE}$, the people of Damascus appealed to Aretas III for help against the advances of the Iturean ruler Ptolemy, the son of Mennaeus. In turn, Damascus accepted him as its ruler and remained under Nabatean control until $72 \mathrm{BCE}$, demonstrating the increased reputation that Aretas had gained beyond the borders of Nabatea. ${ }^{51}$

The simultaneous rise of Nabatea and Judea inevitably pitched the two as rivals. ${ }^{52}$ Alexander Jannaeus' excursions into Transjordan threatened Nabatean power as much as his advances toward Gaza, which served as the Nabatean main gate toward the Mediter-

${ }^{47}$ Cf. Wenning 1994, 3; Bowersock 1996, 18.

48 According to 2 Macc 5.8, Jason fled to Transjordan but was taken captive by the "tyrant Aretas," commonly identified with Aretas I. According to 1 Macc 5.24-27, the Nabateans interacted peacefully with Judas and Jonathan and directed them and their forces to the Jewish communities in the Galaaditis. However, in 2 Macc 12.10-12, the Maccabean brothers were attacked on their march against Timotheus, but the attackers are not clearly identified as Nabateans. The same applies to an attack near Madaba during the rule of Jonathan (1 Macc 9.35-42); in the latter case, the attackers are called as belonging to the tribe of Iambri. 1 Macc 9.35 describes the Nabateans as pí

49 Bowersock 1996, 22; Wenning 2007, esp. 30. For the coinage of Aretas II, see Meshorer 1975, 3, 10-11 and nos. 1-2; Meshorer et al. 2013, 223.

50 Aretas II may be identified with the mysterious Arab king Herotimus in Justin 39.5, who ruled over all Arabs and turned to threatening Egypt and Syria, cf. Sullivan 1990, 73-74; Bowersock 1996, 23.

51 Josephus, $B J 1.103 ; A J 13.392$. The chronology is based on numismatic evidence, cf. Meshorer, 1975, 12-15 and nos. 5-7; Wenning 1994, 4-5; Bowersock 1996, 25; Wenning 2007, 31-32; Meshorer et al. 2013, 224 and no. 8 .

52 Cf. Stern 1981, 24; Kasher 1988, 90-104. 
ranean. ${ }^{53}$ Numerous battles were fought between the two armies with varying outcomes, although Obodas I inflicted a serious defeat on Alexander Jannaeus in 93 BCE near Gadara. The outcome of this battle was a treaty for which Josephus reports no further details, but Alexander Jannaeus apparently lost control over several Transjordan villages and towns. ${ }^{54}$

The peaceful arrangements between Nabatea and Judea did not last for long. Around 82 BCE, Aretas III attacked again and defeated Alexander Jannaeus near Lydda. The Hasmonean king retaliated almost immediately by invading Transjordan and resuming his attacks against the main ports on the Mediterranean. ${ }^{55}$ Once again, expansionist ambitions determined the strategy and political actions on both sides. However, such intermittent skirmishes and territorial disputes did not prevent the evolution of strong diplomatic ties. Treaties - such as the one between Alexander Jannaeus and Obodas - resulted from and reflected the outcome of military conflicts, yet additional hints indicate deeper, more amicable, and more voluntary relations. These become evident, for instance, in the rise and career of the family of the later king Herod the Great. The first known member of this family, Herod's grandfather Antipas, was established by Alexander Jannaeus as governor of his native Idumea, a position he continued to hold under Salome Alexandra. ${ }^{56}$ Idumea was a crucial area for the relationship between the two powers, because the main Nabatean trade routes toward the Mediterranean ran through the region. Antipas fulfilled his tasks to the pleasure not only of his Hasmonean overlords but also their Nabatean allies, as Josephus praises him: "They say that he made friends of the neighboring Arabs and Gazaeans and Ascalonites, and completely won them over by many large gifts." 77

Antipas' diplomatic successes were also shown on the personal level, as Cypros - the wife of his son Antipater and Herod's mother - came from a noble Nabatean family. ${ }^{58}$

${ }^{53}$ For the chronology, see esp. Kushnir 2000-2002. In $A J 13.360$, Josephus states that during Alexander Jannaeus' siege, the inhabitants of Gaza expected to be saved by Aretas. Although they were in this instance disappointed, this hope was not ill-informed, given the importance of Gaza for the Nabatean trade to and across the Mediterranean; cf. Bowersock 1996, 19-20. For the growing diplomatic network of the Nabateans beyond the Near East of the Nabateans see also IPriene 107, 1. 168, dating to $129 \mathrm{BCE}$, which praises a certain Moschion for his embassy to Petra and Alexandria: Bowersock 1996, 22.

${ }^{54}$ Josephus, $B J$ 1.103; $A J 13.375$, 392; Wenning 1994, 4; Bowersock 1996, 24. However, it is noteworthy that Josephus states that Alexander Jannaeus did so in order to prevent Obodas from supporting the internal Jewish opposition. Another consequence of this alliance may have been Alexander Jannaeus' attempt to block Antiochus XII Dionysus' advance against the Nabateans, when the Seleucid king landed around 88/7 BCE (see above). Yet since the Judean troops did not participate in the later war between Antiochus and the Nabateans, the defensive operations may have also only been caused by fear of the advancing Seleucid forces: Josephus, BJ 1.99-100; AJ 389-391; cf. Dąbrowa 2010a, 89-91.

${ }_{55}$ Josephus, $B J 1.104-105 ; A J 13.393-397$; cf. also $A J 14.18$.

56 Josephus, $A J 14.10$.

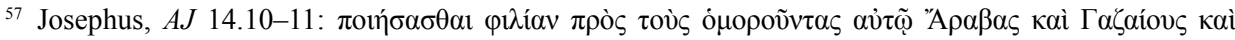

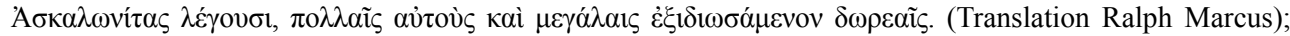
cf. also 14.122 .

${ }^{58}$ Josephus, $A J 14.121$ Josephus calls Cypros as being of noble ancestry, but this should not be interpreted as belonging directly to the core-dynasty since the marriage to a member of the Hasmonean administration, even a high-ranking one, would have been too inferior for Aretas. Yet since the Hasmoneans did not engage in interstate marital alliances, the marriage of two high-ranking members of the courts and aristocracy was a significant bond. That Herod's mother Cypros belonged to the highest echelons of Nabatean society is further proved by the fact that Aretas offered her and other members of Antipater's family refuge during the civil war (Josephus, $A J$ 14.122). 
Nikos Kokkinos has dated this marriage convincingly to around $80 \mathrm{BCE}$ and thus to a time when diplomatic relations between Judea and Nabatea had been firmly established. ${ }^{59}$ These connections on the formal and informal level did not prevent further rivalries; according to Josephus, high-level members of Alexander Jannaeus administration threatened his successor Salome Alexandra that they would defect to the court of King Aretas. ${ }^{60}$ Nonetheless, the friendly ties were maintained, and Antipater persuaded Hyrcanus II later to appeal to Aretas for help, when his brother Aristobulus II had ousted him as high priest and king. ${ }^{61}$

The Hasmonean interactions with the other rising regional power of this period, the Itureans to the North, are even more difficult to reconstruct. However, the successful expansion of both states pitched Judea and the Itureans against each other in ways similar to those discussed above for Judean-Nabatean relations. Although the primary sources hint primarily at military conflicts, it is reasonable to presume the existence of diplomatic contacts in this case as well. ${ }^{62}$ Direct evidence is lacking, but decades after the death of Alexander Jannaeus, the Itureans intervened in the Judean civil war to extend their influence in Judea. Like the Nabateans, they used their ties to the quarreling Hasmonean factions, although they supported the other side with Aristobulus II and his offspring. During this conflict, Ptolemy, the son of Mennaeus, sent his son Philippion to Ascalon to fetch the remaining children of Aristobulus II: Antigonus and his two sisters. Josephus includes these events as part of a romantic court story, as Philippion subsequently married one of the Hasmonean princesses, Alexandra, but was eventually killed by his own father, who had fallen in love with his daughter-in-law and married her after the violent death of his son. ${ }^{63}$ Afterwards, the Itureans continued to support Antigonus' cause and also facilitated the latter's coalition with the Parthians. ${ }^{64}$ Although the background of these actions is unknown, it is hard to imagine that this Iturean intervention was the first diplomatic interaction between the Iturean and Hasmonean dynasties.

Territorial expansion was crucial for Alexander Jannaeus, a desire and strategy that he shared with his peers to the North and the East. The states of the Itureans, Nabateans, and Judeans all benefitted from the disintegration of the Seleucid Empire, as well as from the broader strategic interests of the Roman Republic that kept Ptolemaic imperial ambitions at bay. Yet, by the beginning of the first century BCE, these rising states were hardly fighting for their mere survival and recognition anymore; instead, the region had been turned into an arena of peers that were interacting as equals and competing for gains in territory, power, and international prestige. In the interactions with his peers, Alexander Jannaeus employed a very different approach from that seen above regarding imperial powers. Although the Jews, Nabateans, and Itureans often clashed in military

59 Kokkinos 1998, 95 and 156. Kokkinos dates the marriage to around 80 BCE, because Herod's elder brother Phasael was born no later than 77 BCE (cf. Josephus, BJ 1.203; AJ 14.158).

60 Josephus, $A J 13.414$.

61 Josephus, $B J$ 1.124-125; $A J$ 14.14-18. In exchange for his support, they offered Aretas to return the towns in Transjordan conquered by Alexander Jannaeus in his last raid.

62 Large parts of Galilee had been taken by Aristobulus I from Mennaeus: Josephus, BJ 1.76; AJ 13.318319 (cf. Timagenes, BNJ 88 F 5); Sullivan 1990, 71. For the rise of Iturea at the end of the second and beginning of the first century BCE, cf. Sullivan 1990, 70-72; Myers 2010, 155-156; Wright 2013, esp. 63; Shaw 2014, 236-238.

63 Josephus, BJ 1.185-186; $A J 14.126$.

${ }^{64}$ Josephus, BJ 1.239; AJ 14.126, 330-332. 
conflicts, they also established diplomatic relations and formed amicable ties. These relations did not prevent future tensions, nor were they intended to do so; yet they created a new network of international relations among peers on the formal, semi-formal, and informal level, situated below the ranks of the major powers but also largely independent from imperial interferences. It was this sphere of interactions among peers that Alexander Jannaeus focused on in his foreign policy while ignoring Judea's imperial neighbors as much as possible. This shift in strategy reflected the new political realities on the ground, but it was also an expression of a new Hasmonean self-perception.

\section{A new era, a new approach to interstate relations}

Alexander Jannaeus' 27-year reign over Judea was a tumultuous period, shaped by internal conflicts with an ever-growing opposition, threats by imperial powers, and an aggressive territorial expansion that put the king at odds with his immediate neighbors. Nonetheless, his foreign policy in general proved successful. Despite the fact that Josephus recounts several major defeats that Alexander Jannaeus suffered on the battlefield, Hasmonean Judea reached its greatest extension during his reign, including the permanent annexation of territories in Transjordan, to the North, and at the Mediterranean coast. The drive for expansion was something that Alexander Jannaeus inherited from and shared with his predecessors from the time of Simon on. And, like the earlier Hasmoneans, Alexander Jannaeus benefitted from the continued weakness of the Seleucid Empire ${ }^{65}$ Yet despite these continuities, Alexander Jannaeus diverted from his predecessors' example. Even more than previous Judean rulers, he avoided any conflict with imperial powers at all costs, a strategy that becomes most apparent in his immediate withdrawal from Ptolemais-Acco as soon as Ptolemy IX Lathyrus appeared on the horizon.

There was another side to this caution in all dealings with imperial powers. In contrast to his predecessors, Alexander Jannaeus avoided agreements with any Seleucid claimant to the throne, even if it would have been advantageous for him and Judea. Whereas other Hasmoneans had successfully played the various Seleucid parties against each other, the treaty with Cleopatra III remained the only alliance Alexander Jannaeus entered with a greater power, and it only came into existence in the peculiar situation created by Lathyrus' invasion. As argued above, the knowledge that Cleopatra could hardly have harbored any serious plans to annex Judea increased his willingness in this instance. However, as soon as the immediate danger posed by Lathyrus was gone, Alexander Jannaeus reverted again to his previous strategy and ignored the imperial powers in Judea's vicinity as much as possible. ${ }^{66}$ In contrast, the Judean king showed a very differ-

${ }^{65}$ The dynamic interrelation between the crumbling of Seleucid power and Judean expansion was already noticed by Josephus ( $A J 13.254-255,273)$, although Josephus' chronology is presumably wrong: Barag 1992-1993.

${ }^{66}$ Cf. Stern $(1981,27)$ for Talmudic references to potential relations of Alexander Jannaeus with the Parthian Empire, but the evidence is too scarce and circumstantial to draw any solid conclusions. The same applies to the alleged contacts between Alexander Jannaeus and Mithridates of Pontus in the medieval Yosippon (Rappaport 1968, 338-339; Stern 1981, 28). Zollschan (2017, 259-264) also discusses these references but dates the beginning of Parthian-Hasmonean interactions to the time of John Hyrcanus and his 
ent approach toward his immediate neighbors and peers. His long reign was dominated by quarrels with Greek cities on the coast, the Itureans in the North, and the Nabatean kingdom in the East. Although his army suffered devastating defeats - especially at the hands of the Nabateans - Alexander Jannaeus maintained this strategy of permanent military enterprises, and consequently, he died during one of these campaigns in the North during the siege of Ragaba.$^{67}$ On the other hand, the discussion above has shown that during Alexander Jannaeus' reign, diplomatic relations with his peers, in particular the Nabateans, were established and cultivated. This twofold approach - which combined a general, willful ignorance of imperial superpowers and increased interaction with regional peers - was maintained throughout Alexander Jannaeus' long reign and thus must be interpreted as a general strategy.

The question remains: How did Alexander Jannaeus' decision not to renew the alliance with Rome fit into this new approach to foreign relations? After all, the treaty with Rome had been a safeguard against imperial ambitions, especially those harbored by the Seleucids. Rome had never intervened militarily, even when the Hasmonean state was on the brink of destruction, and it has occasionally been argued that the Hasmoneans were finally frustrated and had lost their trust in the previous alliances. However, it must be noted that Jonathan, Simon, and John Hyrcanus knew all too well that Rome had never sent troops before, even in times of peril, and still opted to renew the alliance. In fact, these rulers commonly sent embassies to Rome immediately after they took office to ensure that the alliance was maintained. Even more so, many treaties with Rome were concluded after significant Hasmonean victories, i.e., when Judea and Judean independence appeared secure. ${ }^{68}$ The alliance with Rome was thus not regarded as a means to achieve this independence, but rather as a further measure to safeguard it. By entering an agreement with the emerging Hasmonean state, the Republic signaled recognition and acceptance, even political support, a decision that was publicized by the Hasmoneans themselves and in the letters that Rome sent to the various parties directly and indirectly involved. ${ }^{69}$ The multiple renewals of the treaty prove that it was this official recognition that the Hasmoneans wanted from Rome, and a formal alliance was the only instrument available in Hellenistic diplomacy to communicate such recognition - even though both parties were well aware that the military

participation in the Median campaign of Antiochus VII. Zollschan's conclusion, however, that the Judean ties to the Parthian Empire were one of the reasons that prompted the Roman Republic to end its alliance with Judea is hardly convincing. Not only was the alliance renewed later in the reign of John Hyrcanus but, more importantly, there is no reason why Rome in the second half of the second century should have objected against friendly relations between the Parthians and Hasmonean Judea.

67 Josephus, AJ 13.398.

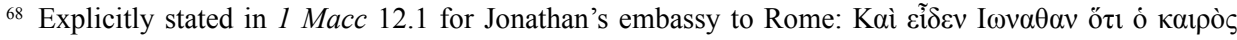

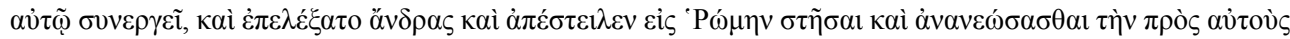

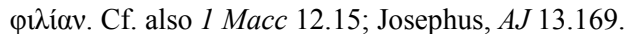

691 Macc 15.16-23; Baltrusch 2002, 93, 105; Wilker 2008, 197-201. Cf. also the assumption in 1 Macc 14.40 that Demetrius II accepted and confirmed Simon as high priest because of the Hasmonean friendship with Rome. There is no solid evidence that the lenient terms Antiochus VII imposed on John Hyrcanus to end the siege of Jerusalem were caused by a Roman intervention, as proposed by Rajak 1981. For a different interpretation see, for instance, Dąbrowa 2010a, 33-34. 
support mentioned in the treaties' stipulations would, in all likelihood, never be sent nor requested. ${ }^{70}$

Against this background, Alexander Jannaeus' decision to divert from his predecessors' strategies appears in a different light. Apparently, he felt that Judea was by now firmly established on the political map of the Near East and a formal recognition by Rome was not needed anymore. In Rome, the decision was presumably not interpreted as a sign of hostility, nor was a renewal at the heart of Roman interest. Seleucid power continued to crumble by internal disputes and secessionists movements even without direct Roman intervention. ${ }^{71}$ It is thus likely that the formal alliance just ceased to exist. From the Judean perspective, Alexander Jannaeus' interactions with imperial states show, to some extent, a similar approach. The king was pragmatic and realistic enough to understand that he should avoid any battle with superior forces if possible. Yet, he also refrained from securing Judea's existence by entering alliances with any of the numerous Seleucid rivals for the throne, which had previously been a standard strategy of Hasmonean foreign policy. Mistrust based on previous experiences of betrayal may have played a role in this decision, but it also reflects a new Hasmonean self-esteem and identity as a rising regional power. The invasions of Ptolemy IX Lathryus and Demetrius III posed a major threat to Judea's territorial integrity, yet they apparently did not affect its self-perception as an independent and growing state that did not need imperial protection anymore.

One may argue that it was already in the second half of John Hyrcanus' reign that Judea changed its character from a young state struggling for independence to an emerging regional power with even more ambitions to fulfill. ${ }^{72}$ However, despite territorial expansion, military successes, and (relative) internal stability, John Hyrcanus remained cautious, and his approach to foreign relations still followed the main established directives, particularly those implemented by his father, Simon. It was only Alexander Jannaeus who felt secure and confident enough to enter a new direction and implement a new strategy in Hasmonean foreign relations, a strategy that was consciously designed to fit Judea's new status and the evolving political situation in the Near East. In this regard, Judea appears increasingly similar to its equally successful and thriving neighbors, such as the Nabateans and Itureans, with whom the Hasmoneans shared a growing confidence, even greater ambitions, and a seemingly insatiable hunger for expansion. Against this background, it is not surprising that most conflicts of this period were fought among these peers.

${ }^{70}$ Cf. Gruen 1984, 751; Baltrusch 2002, esp. 92-93, 104-105, 111-112. This objective is also expressed in Jonathan's letter to the Spartans, explicitly stating that the Jews were in no need for any practical assistance but only sought to revive the alleged traditional friendship between the two peoples (1 Macc 12.8, 14-15; cf. Josephus, $A J$ 13.169).

71 For potential Roman concerns against the expansionist policy of Alexander Jannaeus, see Rappaport 1968; Baltrusch 2002, 110-111; cf. also Shatzman 2012. For the previous Roman strategy to weaken the Seleucid Empire by supporting secessionist movements, cf. the case of Timarchus, satrap of Babylonia (Diod. 31.27a; App. Syr. 45, 47).

72 Cf. esp. Shatzman 2012. The firmly established "international" status of Judea is, for instance, reflected in the decree from Pergamum/Athens, dating to 106/105 BCE: Josephus, AJ 14.150-155, 247-256; Eilers 2006; Eilers 2013, 156-160. 
Alexander Jannaeus' reign thus appears as a turning point in Hasmonean history, not only because of the escalation of internal tensions, the oppression of the opposition, and an unprecedented territorial expansion, but also because of a deliberate and conscious shift in foreign policy. Whereas the king's approach to conflicts within Jewish society did not survive his reign, his strategy for external affairs continued to thrive, and the Hasmonean state with it. Alexander Jannaeus' successor, Salome Alexandra, diverted radically from her late husband's precedent regarding the Pharisees and internal organization of Judea, but she maintained his foreign policy strategy. According to Josephus, she seized power during the siege of Ragaba, which she brought successfully to an end..$^{73}$ In the following years, she enlarged the army even further, allegedly doubling the troops, and turned Judea into an even stronger regional powerhouse. ${ }^{74}$ Unfortunately, Flavius Josephus gives only a rather lacunose account of her reign; but his statement that she "terrified the local rulers around her and received hostages from them" Judea's rise in status. This increase in power is also reflected in another incident in Salome Alexandra's reign that Josephus reports in passing. Just as earlier during Alexander Jannaeus' reign, Damascus found itself again beleaguered by the troops of Ptolemy, the son of Mennaeus; yet this time, the city appealed to the queen of Judea, not the Nabatean king. ${ }^{76}$ Salome Alexandra sent troops under the command of her son Aristobulus, who, according to Josephus, returned "without having accomplished anything noteworthy."77 Regardless of the outcome, the episode testifies to the role of a regional power, a role that Judea had gained during the reign of Alexander Jannaeus and was willing to play.

Josephus recounts Salome Alexandra's intervention in the affairs in Damascus right before one of the major events that would shape the history of the Near East in the first century BCE. Under the rule of Tigranes II, Armenia had evolved into a supra-regional power with imperial ambitions. After the conquest of large parts of Syria, Tigranes besieged Ptolemais-Acco and came close to threatening Judea as well. Salome Alexandra again followed the same strategy her late husband had employed and avoided a military confrontation with superior forces. Instead, she appeased the Armenian ruler with gifts and the establishment of friendly relations. ${ }^{78}$ This move was successful, but it eventually proved unnecessary. Shortly afterwards, Tigranes learned that Roman troops in pursuit of Mithridates VI had invaded Armenia, and the king thus had to hurry back to his homeland. However, these developments were hardly foreseeable, and Salome Alexandra nevertheless proved herself capable of dealing with severe imperial threats and saving her kingdom. Drawing on Alexander Jannaeus' experiences, she knew that an alliance with Rome was not part of this agenda and, at least during her reign, not needed.

73 Josephus, $A J 13.405$.

74 Josephus, $A J 13.409$; cf. BJ 1.112.

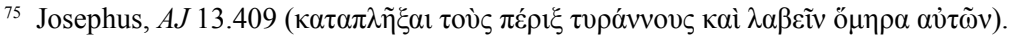

76 Josephus, BJ 1.115; AJ 13.418; Kasher 1988, 107-108; Myers 2010, 157; Dąbrowa 2010 a, 96. Damascus was captured by Tigranes in $72 \mathrm{BCE}$, the latest coins of his reign date to $69 \mathrm{BCE}$, when he left for Armenia: Josephus, BJ 1.116; AJ 13.419-422; Meshorer 1975, 14-15; Bowersock 1996, 26.

77 Josephus, $A J 13.418$.

78 Josephus, BJ 1.116; AJ 13.419-420; Seeman 2013, 233. Rocca (2014a, 286-287) wants to see in the Book of Judith a reflection of Salome Alexandra's supposed stance against Tigranes II. He also purports that she secretly coordinated her response to Tigranes' threat with Lucullus (the same arguments are presented in Rocca 2014b). 
The formal friendship with Rome had played a major role in Judea's struggle for independence - not through military intervention or support but because of the international prestige that the emerging Hasmonean state gained through its alliance with the powerhouse in the West. Ironically, once independence was secured and Judea firmly established on the political map of the Near East and beyond, the official recognition and formal friendship of Rome lost their significance. The end of the alliance with Rome was thus first and foremost a result of previous Hasmonean successes. It was also part of a general reconfiguration in foreign policy, implemented by Alexander Jannaeus from the beginning of his reign. This shift in strategy - marked by a deliberate ignorance of imperial powers and an enhanced focus on interactions with Judea's peers - reflected the new status and self-esteem of the Hasmonean state as a significant and ambitious political player in the region.

The next change in Hasmonean foreign policy, and the approach to Rome, came only after the death of Salome Alexandra in 67 BCE, when her two sons, Hyrcanus II and Aristobulus II, diverted from the strategy set by their parents. Quarreling about who was to succeed their late mother, the rivals appealed to the Roman general Pompey, who had arrived in Syria in the pursuit of Tigranes. Aristobulus' disregard of Pompey's decision eventually prompted the Roman military intervention in Judea, resulting in the conquest of Jerusalem in 63 BCE. Although Pompey eventually decided to reinstall Hyrcanus II in power, Judean foreign policy would never again be independent.

BIBLIOGRAPHY

Amusin, J. (1977), The Reflection of Historical Events of the First Century B.C. in Qumran Commentaries (4Q 161; 4Q 169; 4Q 166), HUCA 48: 123-152.

Atkinson, K. (2016a), A History of the Hasmonean State: Josephus and Beyond, London-New York.

Atkinson, K. (2016b), Understanding the Relationship between the Apocalyptic Worldview and Jewish Sectarian Violence: The Case of the War between Alexander Jannaeus and Demetrius III, in: L.L. Grabbe, G. Boccaccini (eds.), The Seleucid and Hasmonean Periods and the Apocalyptic Worldview, London-New York: 45-57.

Bagnall, R.S. (1976), The Administration of Ptolemaic Possessions outside Egypt, Leiden.

Baltrusch, E. (2002), Die Juden und das Römische Reich. Geschichte einer konfliktreichen Beziehung, Darmstadt.

Barag, D. (1992-1993), New Evidence on the Foreign Policy of John Hyrcanus I, INJ 12: 1-12.

Bowersock, G.W. (1996), Roman Arabia, $4^{\text {th }}$ ed., Cambridge, MA-London.

Cohen, G. (1989), CD VIII 11-12 and Qp Hab IV 10-12, in: E. Van't Dack et al. (eds.), The JudeanSyrian-Egyptians Conflict of 103-101 B.C.: A Multilingual Dossiert Concerning a 'War of Sceptres', Brussels: 33-35.

Cohen, G., Van't Dack, E. (1989), Ptolemaïs-Acco, in: E. Van't Dack et al. (eds.), The Judean-SyrianEgyptians Conflict of 103-101 B.C.: A Multilingual Dossiert Concerning a 'War of Sceptres', Brussels: $124-127$.

Dąbrowa, E. (2010a), The Hasmoneans and Their State: A Study in History, Ideology, and the Institutions, Kraków.

Dąbrowa, E. (2010b), Demetrius III in Judea, Electrum 18: 175-181. 
Dąbrowa, E. (forthcoming), The Seleucids, Rome and the Jews (134-76 BCE).

Ehling, K. (2008), Untersuchungen zur Geschichte der späten Seleukiden (164-63 v.Chr.), Stuttgart.

Eilers, C. (2008), Forgery, Dishonesty, and Incompetence in Josephus' 'Acta': The Decree of Athens (AJ 14.149-155), ZPE 166: 211-217.

Eilers, C. (2013), Diplomacy and the Integration of the Hasmonean State, in: Sh.L. Ager, R.A. Faber (eds.), Belonging and Isolation in the Hellenistic World, Toronto-Buffalo-London: 153-166.

Eshel, H. (2008), The Dead Sea Scrolls and the Hasmonean State, Jerusalem.

Fischer, Th. (1974), Zu den Beziehungen zwischen Rom und den Juden im 2. Jahrhundert v.Chr., ZATW 86: 90-93.

Fischer, Th. (1981), Rom und die Hasmonäer. Ein Überblick zu den politischen Beziehungen 164-37 v.Chr., Gymnasium 88: 139-150.

Giovannini, A., Müller, H. (1971), Die Beziehungen zwischen Rom und den Juden im 2. Jh. v.Chr., Museum Helveticum 28: 156-171.

Goldstein, J.A. (1976), 1 Maccabees: A New Translation with Introduction and Commentary, Garden City.

Gruen, E. (1984), The Hellenistic World and the Coming of Rome, Berkeley-Los Angeles.

Hadas-Lebel, M. (1987), L'Évolution de l'image de Rome auprès des Juifs en deux siècles de relations Judéo-Romaine, $A N R W$ 2.20.2: 715-856.

Hölbl, G. (1994), Geschichte des Ptolemäerreiches. Politik, Ideologie und religiöse Kultur von Alexander dem Großen bis zur römischen Eroberung, Darmstadt.

Huß, W. (2001), Ägypten in hellenistischer Zeit, 332-30 v.Chr., Munich.

Kasher, A. (1988), Jews, Idumaeans, and Ancient Arabs: Relations of the Jews in Eretz-Israel with the Nations of the Frontier and the Desert during the Hellenistic and Roman Era (332 BCE-70 CE), Tübingen.

Kokkinos, N. (1998), The Herodian Dynasty: Origins, Role in Society and Eclipse, Sheffield.

Kushnir, A. (2000-2002), Late Hellenistic Coins of Gaza and the Date of the Hasmonean Conquest of the City, Schweizer Münzblätter 50-52: 22-24.

Meshorer, Y. (1975), Nabataean Coins, Jerusalem.

Meshorer, Y., Bijovsky, G., Fischer-Bossert, W. (2013), Coins of the Holy Land: The Abraham and Marian Sofaer Collection at the American Numismatic Society and the Israel Museum, New York.

Myers, E.A. (2010), The Ituraeans and the Roman Near East: Reassessing the Sources, Cambridge.

Rajak, T. (1981), Roman Intervention in a Seleucid Siege of Jerusalem?, GRBS 22: 65-81.

Rappaport, U. (1968), La Judée et Rome pendant le Règne d'Alexandre Jannée, REJ 127: 329-345.

Rappaport, U. (2013), The House of the Hasmoneans: The People of Israel in the Land of Israel in the Hasmonean Period, Jerusalem (Hebrew).

Rocca, S. (2014a), The Hasmonean State and Rome: A New Appraisal, REJ 173: 263-295.

Rocca, S. (2014b), The Late Roman Republic and Hasmonean Judaea, Athenaeum 102: 47-78.

Schwartz, D.R. (1993), Scipio's Embassy and Simon's Ambassadors, SCI 12: 114-126.

Seeman, Ch. (2013), Rome and Judea in Transition: Hasmonean Relations with the Roman Republic and the Evolution of the High Priesthood, New York.

Shatzman, I. (2012), The Expansionist Policy of John Hyrcanus and His Relations with Rome, in: G. Urso (ed.), Iudaea Socia, Iudaea Capta. Atti del Convegno Internazionale, Cividale del Friuli, 22-24 Settembre 2011, Pisa: 29-77.

Shaw, B.D. (2014), Lords of the Levant: The Borderlands of Syria and Phoenicia in the First Century, SCI 33: 225-242.

Sievers, J. (1990), The Hasmoneans and Their Supporters: From Mattathias to the Death of John Hyrcanus I, Atlanta, GA.

Stemberger, G. (1983), Die römische Herrschaft im Urteil der Juden, Darmstadt.

Stern, M. (1981), Judaea and Her Neighbours in the Days of Alexander Jannaeus, Jerusalem Cathedra 1: 22-46.

Sullivan, R.D. (1990), Near Eastern Royalty and Rome, 100-30 BC, Toronto-Buffalo-London. 
Timpe, D. (1974), Der römische Vertrag mit den Juden von 161 v.Chr., Chiron 4: 133-152.

Van't Dack, E. (1981), Le Conflit Judéo-Syro-Égyptien de 103/102 av. J.-C., in: R. Bagnall et al. (eds.), Proceedings of the Sixteenth International Congress of Papyrology, Ann Arbor: 303-312.

Van't Dack, E. (1989), Les Armées en Cause, in: E. Van't Dack et al. (eds.), The Judean-Syrian-Egyptians Conflict of 103-101 B.C.: A Multilingual Dossiert Concerning a 'War of Sceptres', Brussels: 127-135.

Wenning, R. (1994), Die Dekapolis und die Nabatäer, ZDPV 110: 1-35.

Wenning, R. (2007), The Nabateans in History, in: K.D. Politis (ed.), The World of the Nabataeans, vol. 2 of the International Conference The World of the Herods and the Nabataeans Held at the British Museum, 17-19 April 2001, Stuttgart: 24-44.

Whitehorne, J. (1994), Cleopatras, London-New York.

Whitehorne, J. (1995), A Reassessment of Cleopatra III's Syrian Campaign, Chronique d'Égypte 70: 197-205.

Wilker, J. (2008), Unabhängigkeit durch Integration. Zu den jüdisch-römischen Beziehungen im 2. Jahrhundert v.Chr., in: M. Karrer, W. Kraus (eds.), Die Septuaginta - Texte, Kontexte, Lebenswelten, Tübingen: 194-201.

Wright, N.L. (2013), Ituraean Coinage in Context, Numismatic Chronicle 173: 55-71.

Ziegler, K. (1972), Zoilos 10, RE X A: 714.

Zollschan, L. (2017), Rome and Judaea: International Law Relations, 162-100 BCE, London-New York. 